\title{
Produksi Dan Kandungan Gizi Rumput Gajah (P. purpureum) Dan Rumput Raja (P. purpupoides) Yang Ditumpangsarikan Dengan Tanaman Jati
}

\author{
Nuraini Jamaran \\ Jurusan Ilmu Nutrisi dan Makanan Ternak Fakultas Peternakan \\ Universitas Andalas, Limau Manis Padang
}

\begin{abstract}
This research was objected to study the effect of plant densities on the biomass production and nutrient contents of elephant and king grasses intercropped with teak plant. The teak trees were about 9 months old and planted with the space between trees of $3 \times 3 \mathrm{~m}$. Elephant and king grasses were planted between teak plant in 3 difference densities of: $1.5 \mathrm{~m} \times 0.80 \mathrm{~m}$ (one line density), $1 \mathrm{~m} \times 0.80 \mathrm{~m}$ (two lines density), and $0.75 \times 0.80$ (three lines density). Parameters observed included: plant high, amount of buds/bunch, fresh and DM production, high and diameter of teak trees. Data were statistically analyzed for variance analysis in split plot design. Two kinds of grasses as main plot and 3 plant densities as sub plot with 3 replications. The results showed plant densities gave not significant effect on protein and crude fiber content of grasses, but crop production in both fresh and DM form increased significantly by increasing plant densities. Moreover, the development of teak trees was also significantly affected by grasses. Teak trees intercropped with king grass showed higher tree that intercropped with elephant grass.
\end{abstract}

Key words: elephant grass, king grass, nutritive value, grasses, teak tree.

\section{Pendahuluan}

Hijauan merupakan sumber makanan utama ternak ruminansia untuk dapat memenuhi kebutuhan hidup pokok, berproduksi, dan berkembang biak. Usaha mendapatkan produksi yang optimal dari ternak ruminansia adalah tersedianya hijauan makanan ternak secara kontinu baik kualitas maupun kuantitasnya, hal ini disebabkan karena lebih dari 74 - 94 persen dari total ransum yang dikonsumsi dalam bentuk hijauan disamping kebutuhan konsentrat (Susetyo, 1980).

Pertambahan penduduk dan perkembangan pembangunan di segala sektor akan mengakibatkan semakin sempitnya lahan yang bisa dimanfaatkan untuk menanam hijauan makanan ternak. Keterbatasan lahan ini disebabkan karena lahan subur diprioritaskan untuk tanaman pangan, perkebunan dan pertanian lainnya, sedangkan tanah yang tidak subur dimanfaatkan untuk perumahan, industri dan sebagainya. Kebutuhan untuk hijauan pakan ternak semakin meningkat dengan bertambahnya permintaan terhadap daging terutama berasal dari ternak ruminansia yaitu sapi.

Untuk mengatasi hal ini dibutuhkan kerja sama antara bidang pertanian, perkebunan, kehutanan dan peternakan dalam memanfaatkan 
sumberdaya alam secara efisien dan optimal, antara lain dengan menerapkan sistem agroforestry.

Agroforestry sebagai sistem pertanian kombinasi antara tanaman agronomi, tanaman kehutanan, penghijauan, dan tanaman makanan ternak, pada dasarnya mempunyai dampak yang positif dalam meningkatkan produksi, pendapatan ternak, dan juga berfungsi untuk memelihara kelestarian lingkungan.

Usaha konversi lahan telah digalakkan dengan menanam tanaman tua, diantaranya tanaman jati dengan jarak $3 \times 3 \mathrm{~m}$. diantara barisan pohon jati terdapat ruang tumbuh yang dapat dimanfaatkan untuk menanam rumput unggul diantaranya rumput Gajah (Pennisetum purpureum) dan rumput Raja (Pennisetum purpupoides). Rumput kultivar atau rumput unggul yang ditanam di area pertanaman jati di pulau Jawa dapat menampung kebutuhan ternak 4,5 kali, dibanding rumput lapangan (Nasrum, 1983).

Pertumbuhan dan perkembangan akar tanaman rumput berbeda dengan tanaman jati. Rumput mempunyai akar serabut, tumbuh dari pangkal batang dan akarnya dangkal diatas permukaan tanah, sedangkan jati mempunyai akar tunggang yang dalam, menyerap hara yang masuk kedalam tanah bersama air perkolasi.

Untuk mendapatkan kayu berkualitas baik, jati harus dibuang cabangnya hingga ketinggian $5 \mathrm{~m}$ dari permukaan tanah. Hal ini sekaligus akan memberikan peluang kepada rumput untuk memanfaatkan cahaya matahari yang masuk diantara barisan jati yang subur selama udara dan air masih tersedia.

Penelitian bertujuan untuk mempelajari pengaruh kerapatan tanam dua jenis rumput unggul, yaitu rumput gajah dan rumput yang ditum- pangsarikan dengan tanaman jati, terhadap produksi dan kandungan protein dan serat kasar hijauan serta pengaruhnya terhadap pertumbuhan tanaman jati.

\section{Materi Dan Metode}

\section{Lokasi dan Penyiapan Lahan}

Penelitian dilakukan pada areal perkebunan jati rakyat yang terletak di kanagarian Gurun, Kecamatan Harau, Kabupaten Lima Puluh Kota. Tanaman jati berumur sekitar 9 bulan dengan luas area sekitar $1024 \mathrm{~m}^{2}$.

Dalam penyiapan lahan tanam, lahan dibentuk menjadi petakan sebagai petak utama (main plot). Setiap petak utama kemudian dibagi menjadi tiga blok dan masing masing blok dibagi lagi menjadi tiga anak petak (sub plot) dengan ukuran 9 x $6 \mathrm{~m}$. Pada setiap sub plot terdapat 6 pohon jati.

\section{Penanaman dan Pemupukan}

Selanjutnya diantara tanaman jati pada sub plot ditanam dua jenis rumput unggul, yaitu rumput gajah (Pennisetum purpureum, C.V. Taiwan) dan rumput raja (Pennisetum purpoides).

Masing - masing rumput ditanam dengan kerapatan tanam berupa baris yang berbeda, yaitu:

- satu baris, jarak tanam $80 \times 150 \mathrm{~cm}$

- dua baris, jarak tanam $80 \times 100 \mathrm{~cm}$

- tiga baris, jarak tanam $80 \times 75 \mathrm{~cm}$.

Bibit rumput ditanam berupa stek dengan cara ditugal (olah tanam minimum, OTM).

Pupuk yang digunakan untuk tanaman rumput adalah urea 400 $\mathrm{kg} / \mathrm{ha}$, pupuk kandang 5 ton/ha, TSP $150 \mathrm{~kg} / \mathrm{ha}, \mathrm{KCl} 100 \mathrm{~kg} / \mathrm{ha}$ serta kapur 1,5 kali Al-dd (3,5 ton/ha). Sedangkan tanaman jati diberi pupuk kandang 
100 g, kapur 100 g dan NPK 50 g per batang.

\section{Pemanenan dan Pengambilan Data}

Panen dilakukan setelah tanaman mencapai umur 60 hari. Pemanenan dilakukan dengan cara memotong bagian batang sekitar $10 \mathrm{~cm}$ di atas permukaan tanah. Bobot hijauan dalam bentuk segar ditimbang, kemudian sebagian dikeringkan untuk mendapatkan data produksi berupa bahan kering (BK) serta untuk contoh analisa kandungan protein kasar dan serat kasar.

Satu hari sebelum dipotong dilakukan pengambilan data pertumbuhan tanaman, yaitu:

a. Tinggi rumput $(\mathrm{cm})$, diukur mulai dari permukaan tanah sampai ujung daun dalam keadaan lurus

b. Panjang daun $(\mathrm{cm})$, diukur pada daun yang terpanjang, mulai dari colar sampai ujung daun,

c. Lebar daun (cm), diukur pada bagian tengah daun yang terlebar,

d. Jumlah anakan (batang/rumpun), dihitung dari jumlah batang anak per rumpun dikurangi dengan jumlah tanaman awal.

Disamping itu juga diukur data pertumbuhan tanaman jati berupa data tinggi dan lingkar batang tanaman.
Pengukuran tinggi tanaman dilakukan mulai dari permukaan tanah sampai pucuk tanaman, sedangkan lingkar batang diukur pada ketinggian $15 \mathrm{~cm}$ dari permukaan tanah.

\section{Analisa Statistik}

Data hasil penelitian diuji secara statistik melalui analisa keragaman dengan menggunakan rancangan petak terpisah (Split Plot), yaitu :

a) Petak utama (Main plot) terdiri dari 2 jenis rumput, yaitu rumput gajah (Pennisetum purpureum) C.V Taiwan (=A1) dan rumput raja (Pennisetum purpupoides) $(=\mathrm{A} 2)$

b) Anak petak (sub plot) adalah kerapatan tanam yang terdiri dari satu baris $(=\mathrm{B} 1)$, dua baris $(=\mathrm{B} 2)$, dan tiga baris $(=\mathrm{B} 3)$ antara pohon jati.

Masing - masing perlakuan diulang sebanyak 3 kali (3 kelompok).

\section{Hasil Dan Pembahasan}

\section{Jumlah Anakan dan Tinggi Tanaman}

Rataan jumlah anakan dan tinggi rumput gajah dan rumput raja dapat dilihat pada Tabel 1.

Tabel 1. Jumlah Anakan (batang/rumpun) dan Tinggi Tanaman Rumput (cm)

\begin{tabular}{cccccc}
\hline \multirow{2}{*}{ Parameter } & \multirow{2}{*}{ Jenis Rumput } & \multicolumn{3}{c}{ Kerapatan Tanam (jumlah baris) } & \multirow{2}{*}{ Rataan } \\
\cline { 3 - 5 } & & 1 & 2 & 3 & \\
\hline Jumlah & Gajah & 25,00 & 18,66 & 19,00 & $20,88^{\mathrm{a}}$ \\
anakan & Raja & 44,43 & 40,00 & 48,66 & $44,33^{\mathrm{b}}$ \\
\hline & Rataan & 34,66 & 29,33 & 38,83 & \\
\hline Tinggi & Gajah & 253,33 & 249,33 & 248,67 & $254,43^{\mathrm{a}}$ \\
tanaman & Raja & 137,00 & 204,33 & 203,00 & $201,44^{\mathrm{b}}$ \\
\hline & Rataan & 225,16 & 226,83 & 225,83 & \\
\hline
\end{tabular}


Tabel 2. Produksi Hijauan dalam Bentuk Segar dan Kering (ton/ha)

\begin{tabular}{|c|c|c|c|c|c|}
\hline \multirow{2}{*}{ Parameter } & \multirow{2}{*}{ Jenis Rumput } & \multicolumn{3}{|c|}{ Kerapatan tanam (jumlah baris) } & \multirow{2}{*}{ Rataan } \\
\hline & & 1 & 2 & 3 & \\
\hline Produksi & Gajah & 10.75 & 17.09 & 18.73 & 15.52 \\
\hline Segar & Raja & 7.32 & 14.37 & 18.50 & 13.39 \\
\hline \multicolumn{2}{|c|}{ Rataan } & $9.03^{\mathrm{a}}$ & $15.73^{b}$ & $18.61^{\mathrm{c}}$ & \\
\hline \multirow{3}{*}{$\begin{array}{c}\text { Produksi } \\
\text { Bahan } \\
\text { Kering } \\
\end{array}$} & Gajah & 1.34 & 2.25 & 2.26 & 1.95 \\
\hline & Raja & 1.04 & 1.97 & 3.03 & 2.01 \\
\hline & Rataan & $1.18^{\mathrm{a}}$ & $2.10^{b}$ & $2.64^{\mathrm{c}}$ & \\
\hline
\end{tabular}

Faktor kerapatan tanam tidak memberikan pengaruh yang nyata $(\mathrm{P}>0,05)$ terhadap jumlah anakan dan tinggi tanaman rumput. Sedangkan jenis rumput menunjukkan perbedaan yang nyata $(\mathrm{P}<0,05)$ pada jumlah anakan dan tinggi tanaman. Rumput raja mempunyai anakan yang nyata lebih banyak daripada rumput gajah, namun sebaliknya tanamannya yang nyata lebih rendah. Perbedaan ini disebabkan oleh karena perbedaan genetik dari kedua jenis rumput.

Anakan yang lebih banyak pada rumput raja menyebabkan tinggi tanamannya lebih rendah. Sedangkan rumput gajah mempunyai anakan nyata lebih sedikit dibandingkan anakan rumput raja. Rismundar (1986) mengatakan bahwa rumput raja mempunyai anakan $20-50$ batang dan Djulfiar (1980) mengatakan bahwa anakan rumput Gajah adalah 20 -40 batang.

Menurut Darmawan dan Baharsyah (1983) terjadi penghambatan pertumbuhan pucuk lateral selama pucuk terminal tumbuh normal oleh karena konsentrasi auksin lebih banyak pada titik tumbuh terminal. Kemungkinan pada tanaman rumput gajah konsentrasi auksin lebih banyak pada titik tumbuh terminal sehingga titik tumbuh lateral atau anakan kurang banyak atau kurang berkembang.

Perbedaan genetik dari kedua jenis rumput mendapat respon yang berbeda dari lingkungan yang sama, yang menyebabkan pertumbuhan rumput tersebut berbeda. Akan tetapi produksi bahan kering dan produksi segar rumput gajah dan rumput raja tidak berbeda.

\section{Produksi Segar dan Bahan Kering Rumput}

Rataan produksi segar dan produksi bahan kering rumput gajah dan rumput raja dapat dilihat pada Tabel 2.

Produksi segar dan produksi bahan kering tertinggi dihasilkan dari rumput dengan kerapatan 3 baris, berbeda nyata dengan kerapatan dua baris dan kerapatan satu baris. Mc Ilroy (1997) mengatakan bahwa faktor yang sangat menentukan pertumbuhan tanaman adalah kerapatan dari penanaman. Jarak tanam yang sempit akan menghasilkan rumput yang lebih banyak sehingga produksi bahan kering yang tinggi. Hal ini disebabkan tanaman rumput gajah dan rumput raja yang ditanam dengan kerapatan berbeda mempunyai populasi/ha yang berbeda. Kerapatan tiga baris mempunyai populasi 12.375 rumpun/ha, lebih banyak dari populasi dua baris 
yakni 8.250 rumpun dan satu baris 4.125 rumpun/ha, sehingga lebih banyak menghasilkan produksi segar dan produksi bahan kering yang lebih banyak.

Muhr dan Rost (1951) menyatakan bahwa jarak tanam yang sempit akan meningkatkan produksi tanaman asalkan kesuburan tanah tercukupi. Hal diatas membuktikan bahwa kebutuhan tanaman terhadap hara, air, dan cahaya matahari pada kerapatan satu, dua, dan tiga baris masih tersedia dalam keadaan cukup. Namun demikian jarak tanam mempengaruhi populasi dan efisiensi penggunaan cahaya matahari (Syarief, 1979)

Sutidjo (1986) menjelaskan apabila dua tanaman tumbuh berdekatan tidak akan bersaing satu dengan yang lain selama kandungan air, hara dan cahaya matahari dalam keadaan serba lebih bagi kebutuhan kedua tanaman itu. Tapi bila suatu ketika bahan - bahan itu kurang dari yang diperlukan maka persaingan akan terjadi.

\section{Kandungan Protein dan Serat Kasar}

Tabel 3 menunjukkan bahwa tidak terdapat pengaruh yang nyata
$(\mathrm{P}>0,05)$ antara kerapatan rumput ataupun antara dua jenis rumput yang berbeda terhadap protein dan serat kasar. Hal ini disebabkan rumput gajah dan rumput raja yang ditanam diantara barisan tanaman jati dapat memenuhi kebutuhannya terhadap unsur hara, air dan cahaya, terutama unsur nitrogen sebagai pembentuk protein.

Siregar (1988) dan Suyitman dkk (2003) mengatakan bahwa kandungan protein kasar rumput raja adalah 13,5 $\%$. Kandungan protein kasar rumput gajah $13 \%-14 \%$ dan serat kasar rumput raja adalah $30 \%-32 \%$

Tanaman rumput dengan kerapatan satu baris, dua baris, dan tiga baris mempunyai kandungan protein kasar dan serat kasar yang tidak berbeda, karena belum terjadi persaingan hara dan kebutuhan lain dari rumput.

Tinggi dan Lingkar Batang Tanaman Jati

Lingkar batang tanaman jati yang tumbuh disisip rumput gajah tidak berbeda pada setiap kerapatan. Demikian pula yang disisip dengan rumput raja pada setiap kerapatan sisipan (Tabel 4).

Tabel 3. Kandungan Protein dan Kandungan Serat Kasar Rumput (\%)

\begin{tabular}{|c|c|c|c|c|c|}
\hline \multirow{2}{*}{ Parameter } & \multirow{2}{*}{$\begin{array}{c}\text { Jenis } \\
\text { Rumput }\end{array}$} & \multicolumn{3}{|c|}{ Kerapatan Tanam (jumlah baris) } & \multirow{2}{*}{ Rataan } \\
\hline & & 1 & 2 & 3 & \\
\hline Kandungan & Gajah & 12,96 & 11,95 & 13,34 & 12,75 \\
\hline Protein & Raja & 15,30 & 13,94 & 12,00 & 13,74 \\
\hline \multicolumn{2}{|c|}{ Rataan } & 14,13 & 12,94 & 12,66 & \\
\hline Kandungan & Gajah & 32,36 & 33,25 & 32,10 & 32,53 \\
\hline Serat Kasar & Raja & 34,10 & 34,30 & 34,61 & 34,34 \\
\hline \multicolumn{2}{|c|}{ Rataan } & 33,18 & 33,77 & 33,65 & \\
\hline
\end{tabular}


Tabel 4. Lingkar Batang dan Tinggi Tanaman Jati (cm)

\begin{tabular}{|c|c|c|c|c|c|}
\hline \multirow{2}{*}{ Parameter } & \multirow{2}{*}{$\begin{array}{c}\text { Jenis } \\
\text { rumput }\end{array}$} & \multicolumn{3}{|c|}{ Kerapatan tanam (jumlah baris) } & \multirow{2}{*}{ Rataan } \\
\hline & & 1 & 2 & 3 & \\
\hline \multirow{2}{*}{$\begin{array}{l}\text { Lingkar } \\
\text { batang }\end{array}$} & Gajah & 1,83 & 1,00 & 1,25 & 1,36 \\
\hline & Raja & 5,33 & 4,25 & 1,00 & 3,25 \\
\hline \multicolumn{2}{|c|}{ Rataan } & 3,58 & 2,62 & 1,12 & \\
\hline \multirow[t]{2}{*}{$\begin{array}{c}\text { Tinggi } \\
\text { tanaman }\end{array}$} & Gajah & $\begin{array}{c}31,50^{\mathrm{a}} \\
\mathrm{A}\end{array}$ & $\begin{array}{c}26,33^{\mathrm{a}} \\
\mathrm{B}\end{array}$ & $\begin{array}{c}29,83^{\mathrm{a}} \\
\mathrm{B}\end{array}$ & $29,22^{\mathrm{a}}$ \\
\hline & Raja & $\begin{array}{c}51,16^{\mathrm{b}} \\
\mathrm{A}\end{array}$ & $\begin{array}{c}46,83^{\mathrm{b}} \\
\mathrm{AB}\end{array}$ & $\begin{array}{c}44,83^{\mathrm{b}} \\
\mathrm{B}\end{array}$ & $47,66^{\mathrm{b}}$ \\
\hline \multicolumn{2}{|c|}{ Rataan } & 41,33 & 36,08 & 37,32 & \\
\hline
\end{tabular}

Keterangan: $\mathrm{AB}$ berbeda nyata menurut baris ab berbeda nyata menurut kolom

Jati yang disisip dengan rumput gajah pada kerapatan sisipan satu baris nyata lebih tinggi dari jati yang disisip dua baris dan tiga baris. Tinggi tanaman jati yang dua baris tidak berbeda nyata (P> 0,05) dengan yang disisip tiga baris.

Jati yang disisip dengan rumput gajah ternyata lebih rendah daripada jati yang disisip rumput raja pada setiap kerapatan. Tinggi jati yang disisip rumput raja pada kerapatan satu baris berbeda nyata dengan yang disisip tiga baris dan tidak berbeda nyata dengan yang disisip dua baris.Tanaman jati yang paling tinggi adalah yang disisip satu baris dengan rumput raja. Harianto (1986) menyatakan jarak tanam yang terlalu rapat akan menghambat pertumbuhan dan terlalu renggang akan menyebabkan tumbuhnya gulma.

Tanaman jati yang disisip rumput gajah nyata lebih pendek dibandingkan dengan jati yang tumbuh dengan sisipan rumput raja, tetapi tidak lebih pendek dibandingkan dengan jati kontrol yang mempunyai tinggi $31 \mathrm{~cm}$ dan lingkar batang $1,87 \mathrm{~cm}$.

\section{Kesimpulan}

Dari hasil penelitian dapat disimpulkan bahwa kerapatan atau jarak tanam berpengaruh terhadap produksi hijauan rumput gajah dan rumput raja yang ditanam diantara tanaman jati. Semakin rapat jarak tanam, produksi hijauan semakin meningkat baik dalam bentuk segar maupun berat kering. Sedangkan kandungan protein dan serat kasar hijuan dari kedua jenis rumput tidak dipengaruhi oleh jarak tanam. Selanjutnya, kedua jenis rumput memberikan pengaruh yang berbeda terhadap pertumbuhan tanaman jati. Tanaman jati yang ditumpangsarikan dengan rumput raja ternyata memiliki pohon yang lebih tinggi daripada yang ditumpangsarikan dengan rumput gajah.

\section{DAFTAR PUSTAKA}

Darmawan J. dan Yustika S. Baharsyah. 1983. Dasar-dasar Fisioligi Tanaman. P.T Suryandaru Utama, Semarang.

Djulfiar. 1980. Rumput Gajah Departemen Pertanian Balai Informasi Pertanian. Unggaran Jawa Timur. Bull. Vol IV. 1979/1980

Harianto, P.B. 1986. Pengaruh Pemupukan Nitrogen dan Jarak Tanam terhadap Pertumbuhan 
dan Produksi Stevia Rembaudiana. Bertoni. M. Tesis Sarjana Pertanian IPB, Bogor.

Mc.Ilroy, R.J. 1977. Pengantar Budi Daya Padang Rumput Tropika. Pradnya Paramita, Jakarta.

Nasrum, 1983. Eksplorasi Budi Daya Tanaman Pakan dalam Ekosistem Hutan Jati Implementasi Agrohutani di Banyumas Barat. Universitas Padjadjaran, Bandung.

Rismunandar. 1986. Mendayagunakan Tanaman Rumput. Sinar Baru, Bandung.

Sarief, E.S., 1986. Kesuburan Tanah dan Pemupukuan Tanah Pertanian. Pustaka Buana, Bandung.

Alamat Korespondensi: Ir. Nuraini Jamaran Jurusan Nutrisi dan Makanan Ternak Fakultas Peternakan Universitas Andalas Limau Manis, Padang, Sumatera Barat. Telp. : 0751-29643 HP: 08126749318

Artikel diterima: 27 April 2006, disetujui: 16 Mei 2006. IPB, Bogor.
Siregar, M.E., 1988. Apa Itu King Grass. Pusat Penelitian Pengembangan Peternakan, Departemen Pertanian, Jakarta.

Susetyo, S., 1980. Padang Pengembalaan. Fakultas Peternakan IPB, Bogor.

Sutidjo, 1986. Pengantar Sistem Produksi Tanaman Agronomi. Diktat Kuliah Jurusan BDP,

Suyitman, dkk., 1977. Produksi dan Kandungan Gizi Rumput Raja (Pennisetum purpupoides) Pada Tingkat Naungan dan Pemupukan Berbeda. Lembaga Penelitian Universitas Andalas Padang.

Artikel diterima: 27 April 2006, disetujui. 16 Mei 2006. 